\title{
WALT WHITMAN, CLARENCE MAJOR, AND CHANGING THRESHOLDS OF AMERICAN WONDER
}

\author{
Linda Furgerson Selzer
}

Although Walt Whitman never ventured further into the West than his 1879 trip to Colorado, his imagined Western landscapes play a central role in the distinctively American poetic voice that energizes the multiple editions of Leaves of Grass. Contemporary African American poet, novelist, and painter Clarence Major has lived and worked for much of his adult life in the West, so it is not surprising that its material and figurative landscapes are also central to his multiple artistic projects. In addition, Major consciously engages Whitman's imagined West in his essays and poetry, and his poem set on the coast of Northwestern California, "September Mendocino," is a direct response to Whitman's better-known "Song of the Redwood-Tree." Whitman's poem, composed in the year after his paralytic stroke on January 23, 1873, was first published in Harper's New Monthly Magazine in 1874. "September Mendocino," written in 1995, was first published in Configurations, a 1998 anthology of Major's poetry. Although over one-hundred years separate their imaginative encounters with the Western landscape, both poems map the contours of the national imaginary onto that territory. Considered together, "Song of the Redwood-Tree" and "September Mendocino" trace the trajectory of changing thresholds of American wonder.

When "Song of the Redwood-Tree" was published, Mendocino County, California, was just twenty-four years old, one of the original twenty-seven counties that were established with statehood in 1850. The pre-historic home of Native Americans, estimated to have lived in the area from 7,000 BC, Mendocino saw the first long-term Spanish settlements in the mid-1600s and the first non-Spanish, European American settlements in 1852 - just four years after gold was discovered at Sutter's Mill. In the same year newspapers across the country ignited the nation's imagination with reports of the "discovery" of giant redwoods in the Sierra Nevada. Only a scant year afterwards, traveling redwood exhibits began to make the four-month journey from San Francisco to the Eastern seaboard, and by 1856 exhibits traveled all the way to the 
Crystal Palace in London. ${ }^{1}$ For most Americans in Whitman's lifetime, their first contact with an actual redwood tree would in fact not be in its natural habitat but through these traveling bark exhibits and within the context of the nineteenth-century discourses of discovery and progress to which they contributed. ${ }^{2}$

When Major published his late twentieth-century poem, the Mendocino coastline had taken on a rather different character. Perched high on a cliff above the headland where the Big River empties into the Pacific, the scenic town of Mendocino is now one of the favorite stops for wine tourism on the northern California coast. While the quaint village is far separated from the rough-and-tumble logging area to which Whitman tied his hopes for the nation's future, it is clear that the discovery of Whitman's poetry played an important role in Major's conception of poetic possibility. In an essay entitled, "Discovering Walt Whitman," Major describes his amazement when, as a young black man growing up on the South Side of Chicago, he first came across Whitman's Leaves of Grass in "a Catholic Salvage Store." ${ }^{\text {A }}$ As he explains, "there was never any Whitman in school. There was Shakespeare. Whitman was too revolutionary for South Side high schools" $(N D, 30)$. Finding special importance in Whitman's struggle against "social restrictions," Major groups his discovery of the poet with those he made of Paul Laurence Dunbar and Phillis Wheatley. Later, when working on the Dictionary of Afro-American Slang, Major found Whitman's comments about language instructive, especially his observation that language "is not an abstract construction of the learned, or of dictionary-makers, but . . . has its basis broad and low, close to the ground" (qtd. in ND, 30). Long before he wrote "September Mendocino," then, Major's "discovery" of Whitman seemed to capture the aspiring writer's growing sense of the capabilities of language and the promise of his own artistic future.

But Major's Mendocino poem demonstrates a more critical engagement with Whitman, and, more pointedly, with the linked discourses of natural wonder and technological progress that energize "Song of the Redwood-Tree." In an 1873 manuscript, Whitman writes that the poem was designed to "express fully [his] California views." "After the horrors of the Civil War had scarred the Eastern landscape, Whitman relocated his millennial hopes for the nation's future to the California West. The logic of "Song of the Redwood-Tree" unfolds-somewhat illogically - by drawing upon the public's fascination with a natural wonder in order to bolster admiration for the nation's unfolding technological achievements, understood as an engine for the realization of manifest destiny. ${ }^{5}$ Through its death chant, the redwood tree reveals that it lays down its life willingly, a noble sacrifice to the "grander future" anticipated by the poem's last line. ${ }^{6}$ 
Although the few descriptions of the workers' song in Whitman's poem - the "music of the choppers' axes" and the "echo of teamsters' calls"-might strike readers as mere background music to the redwood's featured voice, the workers are in fact positioned as the poem's effective force (LGVar., 3:677). ${ }^{7}$ The logger's actions, the "crackling blows of axes sounding musically driven by strong arms," occasion the redwood's song (LGVar., 3:674). As the redwood submits, so too do the poem's ancient forest spirits, the dryads, who "withdraw" and "yield" at the "crash" of falling trees (LGVar., 3:677). Rather than criticizing the workers for felling a natural wonder, the poem positions the loggers as the visible agents of the nation's "hidden national will" (LGVar., 3:676). ${ }^{8}$ Whitman thus attempts to evoke readers' feelings of nostalgia at the passing of a natural marvel - at the time individual redwood trees were believed to be over 3,000 years old - and then to redirect or channel those emotions into a celebration of America's yet-unrealized future: to turn nature's requiem into a national anthem. No wonder some critics have seen in the poem "a conservationist's horror."

By the operation of the poem's logic, the age of the redwood ultimately serves only to magnify the importance of the "genius of the modern," including the industry of the workers who bring the tree down (LGVar., 3:678). The linking of ancient wonder with the logger's labor and with technological progress was in fact a common feature of the discourse that attended traveling redwood exhibits during Whitman's lifetime. Readers today may be more familiar with another popular category of exhibit discourse, one designed to emphasize the size of the redwoods by picturing them next to teams of horses or with groups of people posed next to them (or, in some cases, with people dancing on top of the redwood stumps). But a number of redwood advertisements, illustrations, and photographs in the nineteenth century chose instead to feature both the redwood's awe-inspiring attributes and the technological feats required for its so-called "harvesting." broadsides advertising the redwood exhibitions coupled measurements meant to evoke astonishment at the height or girth of the trees with statistics designed to evoke amazement at the difficulty required to bring them to exhibit. An 1854 broadside for the first giant redwood to be cut and exhibited in the East-a section of the bark of the "Discovery Tree" harvested in 1853 and exhibited on Broadway - gives the tree's vital statistics as "3,000 years old, 325 feet in height" and then marvels that it required the "the labor of ten men for twenty-six days in felling it, which was effected by boring through the immense mass with pump augers" (Figure 1).

The work required to bring redwood sections to exhibit is illustrated in more detail in an advertisement for the Mother of the Forest exhibit 


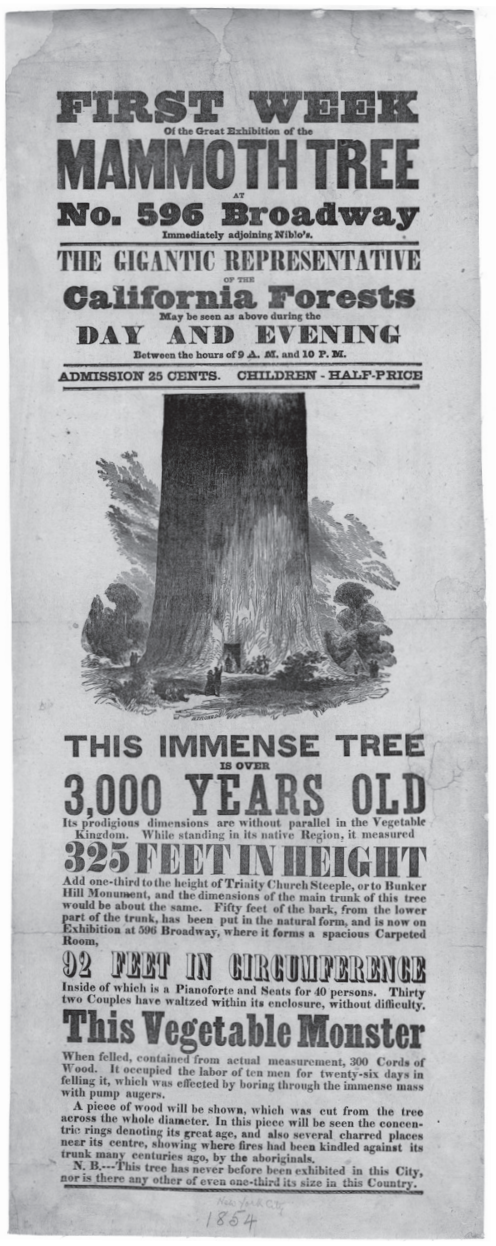

Figure 1. Captain Hanford. Broadside announcing Hanford's Big Tree Exhibit on Broadway, 1854. Collection of the NewYork Historical Society. Image 60618. Reprinted with the permission of the NewYork Historical Society.

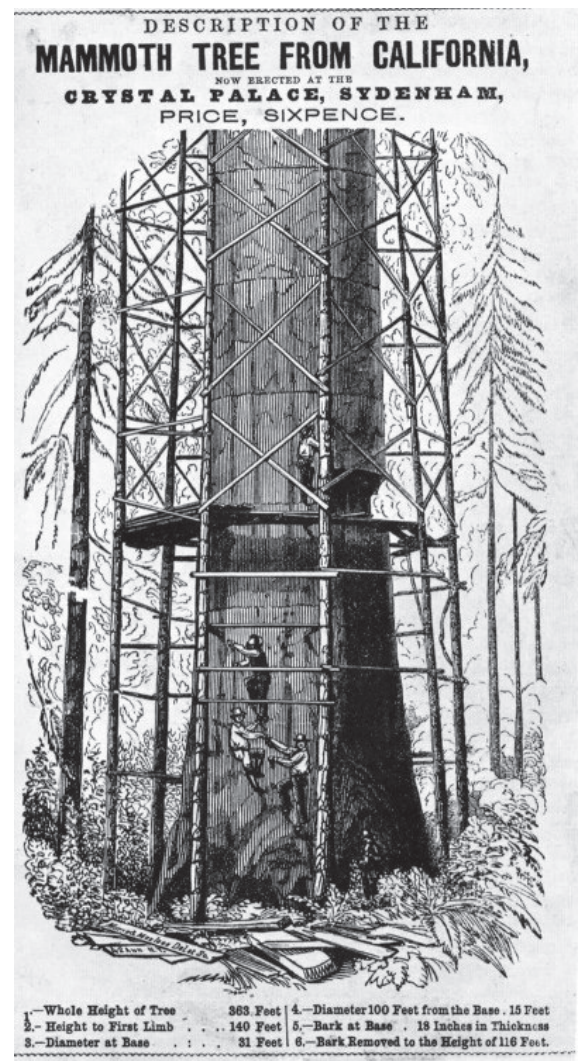

Figure 2. 1858 advertisement for the Mother of the Forest tree exhibited in the Crystal Palace, Sydenham Hill, England. Reprinted with the permission of the Crystal Palace Archives.

(which appeared at New York's Crystal Palace in 1855 and at England's beginning in 1856). An 1858 broadside advertising the English exhibit features the elaborate scaffolding required for workers to harvest the bark (Figure 2). Indeed, the public's interest in the industrial techniques used to harvest redwoods can be traced all the way from the 1853 felling of the Discovery Tree to the 1893 harvesting of a section of the General Noble redwood for Chicago's Columbian Exhibition (and beyond). At 
the Columbian Exhibition, the General Noble tree was placed near a series of photographs of workers constructing the redwood section by photographer C. Curtis. ${ }^{11}$ The inclusion of both descriptions and depictions of the feat of harvesting the redwood sections for exhibition probably served several purposes. Exhibit promoters clearly believed that the sense of awe generated by their redwood sections would be increased, rather than diminished, by the inclusion of information about the techniques used to harvest them. Illustrations and photographs could also serve to bolster the authenticity of exhibits. The pairing of tree sections with illustrations of loggers' work also contextualized the redwood exhibits as the result of larger technological forces that were increasing the speed with which products and people - and wonders from various locales - could circulate the globe. In "Song of the Redwood-Tree," Whitman also ties the redwood's felling to such processes of globalization: "Ships coming in from the whole round world, and going out to the whole world" (LGVar., 3:678). ${ }^{12}$

In his 1862 Scenes of Wonder and Curiosity in California, James M. Hutchings includes an illustration of the 1853 felling of the Discovery Tree with a discussion of the significance of its harvesting. ${ }^{13}$ Hutchings's work is pertinent here partly because it was popular enough to be republished in New York in 1870 and again in 1872, in the period immediately before Whitman composed "Song of the Redwood-Tree." In fact, Hutchings closes his description of the "Calaveras Redwoods" with a statement that seems to invite the composition of Whitman's poem: "Could those magnificent and venerable forest giants of Calaveras county be gifted with a descriptive historical tongue, how their recital would startle us, as they told of the many wonderful changes that have taken place in California within the last three thousand years!" Hutchings's illustration of the felling of the Discovery Tree is accompanied by a detailed description of the process used to bring the tree down (Figure 3). Unlike Whitman's poem, however, Hutchings includes a strong condemnation of the felling of the tree, calling it a "sacrilegious act."

Rather than condemning the workers' felling of redwoods, like Hutchings, Whitman positions the workers as historical agents of the "genius of the modern ...

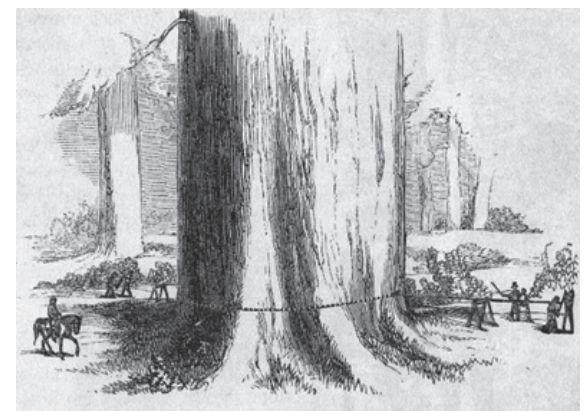

Figure 3. Print illustrating the harvesting of the Discovery Tree with pump augers. From James M. Hutchings, Scenes of Wonder and Curiosity in California" (San Francisco: J. M. Hutchings and Co., 1962), 43. 
/ Clearing the ground for broad humanity" (LGVar., 3:678-679). As I argue here, Whitman's "Song of the Redwood-Tree" thus contributes to a larger nineteenth-century cultural discourse, one shared by advertisements for redwood exhibits, which tied the discovery of the redwoods to industrial progress from the moment the giant trees first entered the national imaginary. Although it is mostly forgotten today, tourists who attended the traveling redwood exhibits were sometimes encouraged to sign a registry to document for succeeding generations that they had actually witnessed the awe-inspiring giant. ${ }^{14}$ In "Song of the Redwood-Tree," Whitman leaves a registry of his own "California views": an aesthetic of wonder created through the interplay of technological feat and natural marvel.

By challenging the logic of Whitman's "Song," while simultaneously critiquing the discourse of wonder characteristic of its own late twentieth-century period of composition, Major's "September Mendocino" performs a complex double gesture. Looking out the window of his Mendocino bed and breakfast, the speaker of Major's poem sees "Walt's spirit swimming / out in the Pacific with its boots on, / but still being clear / about ... the 'voice / of a mighty, dying tree / in the redwood forest dense." ${ }^{\prime 15}$ At the same time that he evokes Whitman's presence, the speaker makes clear that he finds the poet's prophetic stance to be untenable-like swimming with one's boots on. As he comments, "it's not the same there, anymore, Walt" (257). Reflecting on the differences between their respective time periods, the speaker remarks, "No bark a foot thick here. / No. This is 1993, tree for tree. / How many of the giant spirits / of 1874 still stand as I wash / my hands in the California coastal water?" (255). The poem's juxtaposition of historical periods signals the speaker's implicit critique of the celebratory expansionism of Whitman's day that contributed to the loss of great redwood forests; at the same time, however, it prompts the speaker to question his own poetic project at the approach of the millennium. Wondering what voices a traveling poet might hear in Mendocino today, the speaker finds that the answer comes in overheard tourist chatter about the charms of the Joshua Grindle Inn-about "Jim's freshly baked muffins" and "the cottage out back" (256).

Indeed, the title of Major's poem, "September Mendocino," evokes both the "fall" or decline of the Mendocino coastline from its previous inspirational grandeur and the very month when the area is now host to its most popular tourist festivals, including Winesong, its longest-running wine tasting event, and Paul Bunyan Days, designed to attract visitors by featuring activities inspired by the region's logging past. Not surprisingly, the discourses of wonder to which Major refers in crafting his poem are those provided by a modern tourist 


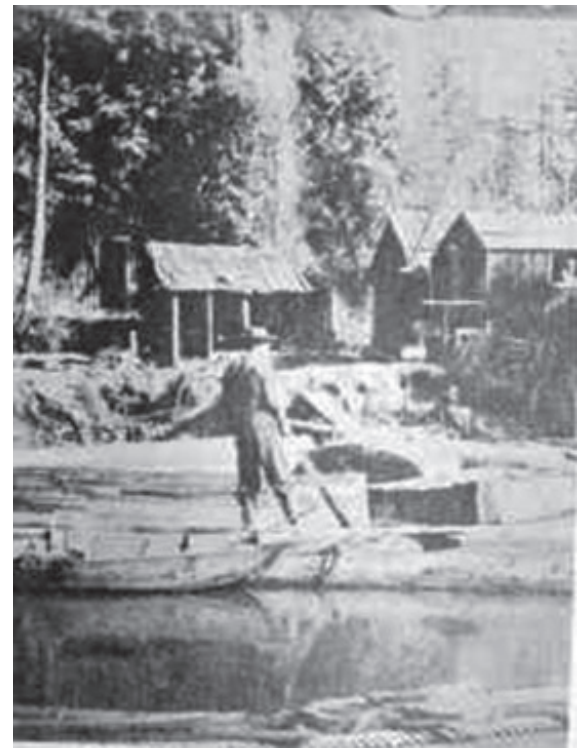

Figure 4. Photograph of Joshua Grindle at camp in the 1870 s. Photo by C. E. Watkins. Printed with permission of the Mendocino Historical Society and the Held Poage Memorial and Research Library (from the collection of Robert Lee). culture, a discourse that-ironically, but not surprisingly-calls upon the area's logging history to indulge in a sort of "second-hand wonder-making." For example, on-line advertisements for the actual Joshua Grindle Inn promise visitors a "romantic walk through history" and emphasize the fact that the Inn was built by one of the town's original loggers, Joshua Grindle (Figure 4). ${ }^{16}$ And in fact the historical Grindle's later success as a banker eventually enabled him to build the nineteenth-century house that would become the twentieth-century tourist retreat visited by Major's speaker (and by Major himself). Modern tourist literature for Mendocino thus attempts to evoke a sense of wonder by appealing to the logging past of Whitman's day, while Major's poem develops an ironizing effect by contrasting the millennial

future anticipated in Whitman's poem with today's everyday tourist culture.

In theorizing postmodern forms of irony, Linda Hutcheon suggests that nostalgia often appears in postmodern works "with the kind of ironic double vision that acknowledges the final impossibility of indulging in nostalgia, even as it consciously evokes nostalgia's affective power. In the postmodern, in other words . . . nostalgia itself gets both called up, exploited, and ironized."17 Major's Mendocino poem achieves these multiple effects in part by calling up the presence of Whitman as a problematic precursor to today's poet/speaker. In other words, the Whitman of Major's poem represents a particular poetic project which the speaker judges to be both no longer available to him and problematic in its own right. Whitman's speaker, confident of his ability to serve as nature's interpreter, believes that he can "hear the voice" of the redwood that others cannot hear, and he anticipates the coming of a "new society at last, / proportionate to Nature" (LGVar., 3:678). As M. Jimmie Killingsworth suggests, the speaker of Whitman's poem understands himself as the "privileged spokesman for 
nature" (66). Writing after the privileging of poetic imagination has been chastised by thinkers from Freud to Derrida, Major's speaker occupies a position of epistemological doubt that undermines a prophetic stance. Indeed, as a citizen of a new American society rather unlike the one anticipated by Whitman, Major's speaker discovers that efforts to understand the nation as somehow proportionate to nature fail. At one point the speaker tries to measure the depth of the Big River against the height of the town, questioning:

How deep is the river - is it as deep as it was?

It's deeper than the gift shops are high.

That's for sure. Deeper than

Rainsong Shoes or Paper Pleasures,

...

But really, how far down is that river? (258)

Writing in an interrogative rather than a prophetic mode and critical of an assumed correspondence between natural and human orders-between the depth of the river and the height of the tourist shops-Major's speaker confronts his own poetic limitations: he finds himself unable to sound the river's depths.

A similar perspective is brought to bear on Whitman's speaker's attempt to identify the "unseen moral essence" believed to unify the California landscape and direct the nation's future (LGVar., 3:676). Looking at the shanties described in tourist guides as some of the "original" buildings in Mendocino, Major's speaker wonders whether they are really "the remains / of the big camp shanties of the 1870s," and questions, "What is their 'unseen moral essence,' / compared to, say, the trendy gift shops / and their objectives" (258). His question cuts in two directions. While it criticizes the shops of the present as "trendy," undercutting the seeming moral imperative with which Whitman imbues the "genius of the modern," it also draws a distinction between the shops' relatively inconsequential form of commercialism and the exploitation practiced on a grand scale by the town's original mills - the effects of which still mark the Mendocino countryside.

Whitman's transcendental identifications are also placed under suspicion by Major's speaker, but at some cost to the presumed reach of the contemporary poetic imagination. What Major's speaker calls the "romance" of Whitman's dryads is translated into the "romance in our oceanview room," as the sailing ships that travel the "round world" in "Song of the Redwood-Tree" are reduced to the "tiny sailboat wallpaper" that decorates the Joshua Grindle Inn (258). More significantly, Whitman's "Song" asserts that the redwood tree "bear[s] the soul befitting $[i t]$," and enumerates the tree's stately pleasures of "joys 'mid rain and 
many a summer sun" (LGVar., 3:675). In response, the speaker in Major's poem reflects, "Do we any longer see what is befitting"(255). He thereby raises the important question of what pleasures might be "appropriate" or "befitting" for the contemporary soul. In the sixth stanza, the speaker considers the enjoyment to be found visiting the natural sites described in tourist guides - sites such as Russian Gulch (known for its sea-cave), or Headlands Park (famous for its dramatic cliffs). By "skipping" these sites, he wonders, would a visitor leave with "less than a tourist should" (255). Major's comment reduces the complex spiritual identifications associated with nineteenth-century encounters with natural wonders to jaded contemporary deliberations over what tourist stops to fit into a busy traveler's schedule. "September Mendocino" thus critiques both Whitman's mystical stance toward the natural world and the ennui of contemporary tourists who feel less a sense of awe at natural wonders than an obligation to visit them.

In "September Mendocino" Major reflects upon his own poetic project nearly fifty years after he was first inspired by Whitman's verse as a young man. In the first stanza of his poem Major unmistakably places his speaker/alter ego in the Western locale of Whitman's earlier poem, beginning with the question, "What do you hear up here? / Same Shasta air, same Nevada air, / same Sierra Nevada air, same rainsong air / that lured Wait [sic] Whitman when he heard it" (254). The repetition of place names from "Song of the Redwood-Tree," combined with the use of the word "lured," suggests that Major's speaker is not immune to the transcendental invitations offered by Whitman's imagined Western geography - although he is suspicious that those enticements may comprise a siren's song. The speaker's unfolding criticism of Whitman's project leads him to question his own poetic venture; "is it," he wonders, "necessary to still sing a California song" (255). In spite of his unfolding critique of Whitman's romantic representation of the nineteenth-century Mendocino coastline and his own ironic engagement with the same territory in the twentieth century, Major's speaker ultimately answers this question in the affirmative: "The song has nothing to do with whether or not / this year is like Walt's year. It has to do with air, / this air, this new air . . / singing through the redwoods' cold nights" (255). Leaving the place names of Whitman's poem behind and focusing on Mendocino as it reveals itself to him in the concrete, quotidian, and even banal sights and sounds of everyday tourist pleasures, Major's speaker attempts to resist the temptation to aggrandize and inflate. Ironically, it is perhaps by this decision that he best proves himself the student of Whitman's understanding of language-as having "its basis broad and low, close to the ground."

At the time Major was first drafting his Mendocino poem in 1993, operations were being completed to salvage first-growth redwood logs 
that had lain at the bottom of the Big River for over one-hundred-andfifty years. One of the purposes to which these first-growth redwoods were put was the building of the Brewery Gulch Inn, a California bed and breakfast that now advertises the sale of "eco-salvaged" logs. Tourists buy the logs to have them made by local artists into souvenirs that range from walking sticks to dulcimers. Through a process of second-hand wonder-making, Whitman's noble giants become the trendy souvenirs of today's Mendocino tourists. The Brewery Gulch Inn's promotional materials emphasize that the salvaged, first growth redwood is extremely rare, as is the B\&B itself, "where your senses will be awakened, your comfort assured, and your soul stirred." 18 In "September Mendocino," Major suggests that just such pleasures may be those that "befit" the contemporary soul.

If Walt Whitman structures "Song of the Redwood-Tree" in part as an anthem to the nation's "grander future," Clarence Major offers a coda to that composition from the present. Against Whitman's millennial imagining of a grander nation to come, Major's "September Mendocino" wryly presents a contemporary landscape defined by commonplace tourist discourses. Adopting an intertextual method that asks readers to reflect upon both nineteenth- and twentieth-century uses of the imagination, Major contrasts Whitman's geography of manifest destiny and bardic aspirations with a site of commercial semiosis and the banalization of memory. By doing so, he maps a new terrain of American wonder.

\section{Pennsylvania State University-University Park}

\section{NOTES}

1 The many redwood exhibitions in the nineteenth century have led to some confusion in the secondary literature over places of exhibition, dates, and types of trees exhibited. For a detailed history of redwood exhibitions that unravels much of this confusion, see Dennis Kruska, Sierra Nevada Big Trees: History of the Exhibitions, 1850-1903 (Los Angeles: Dawson's Book Shop, 1985).

2 It should be noted here that the coastal redwoods (Sequoia sempervirens) and the giant redwoods (Sequoiadendron giganteum) are separate varieties that were both exhibited in the East. Coastal redwoods are native to the Mendocino area. During the nineteenth century there was confusion between the two species. Ironically, some exhibit goers in the East found the diameter of the reconstructed exterior bark of the giant redwoods to be so unbelievable that they assumed the trees were hoaxes, while believing the coastal redwoods to be more authentic. For example, as late as 1876, the General Noble tree, named after Union General John Willock Noble, was widely thought to be a hoax.

3 Clarence Major, Necessary Distance: Essays and Criticism (Minneapolis: Coffee House Press, 2001), 29. Hereafter, ND. 
4 Walt Whitman, "Song of the Redwood-Tree." 1873 Manuscript. The Papers of Walt Whitman. Albert and Shirley Small Special Collections Library, University of Virginia. MSS: 3829: 5604. Available on the Walt Whitman Archive (whitmanarchive.org).

5 Diane Kirk has previously suggested that the few descriptive details of actual redwoods found in Whitman's poem (such as the tree's "foot-thick bark") echo those found in the descriptions of the Mother of the Forest exhibit tree. Kirk, however, rejects the idea that the exhibits were a primary influence on Whitman's poem, pointing out that Whitman did not write about redwoods in the 1850 s when people were "flocking" to exhibitions (10), but in the 1870s when Asa Gray was publishing his theories about redwood evolution. Yet popular redwood exhibits did take place in the 1870s (and long afterward) in New York and in other cities. In 1871, for example, redwood exhibits attracted crowds in New York's Central Park and at 587 Broadway (Krusha, 57). In addition, high culture discussions of the redwoods like Gray's and mass culture practices like the exhibits should not be understood as opposed phenomena, but as related discourses in circulation during the nineteenth century - a point confirmed by the short quotations from Gray that can be found on some redwood exhibit broadsides. It is likely that Whitman was influenced by both the scientific and popular discourses in circulation about redwoods during his lifetime. In any case, Kirk's insightful analysis of the Neo-Lamarckian aspects of Whitman's poem does not analyze the traveling exhibits' dual emphasis on natural and technological feat. See "Landscapes of Old Age in Walt Whitman's Later Poetry" (Ph.D. Dissertation, Texas A\&M University, 1994).

6 Walt Whitman, "Song of the Redwood-Tree," Leaves of Grass: A Textual Variorum of the Printed Poems, ed. Sculley Bradley, Harold W. Blodgett, Arthur Golden, and William White (New York: New York University Press, 1980), 3:679. Hereafter, LGVar.

7 In reference to the workmen's "calls," it is interesting to note that an early manuscript version of one portion of the poem appears on the back of a leaf in which Whitman imagines writing a poem about the calls of various occupations. Whitman, "Song of the Redwood-Tree," 1873 Manuscript. The Trent Collection of Walt Whitman Manuscripts. Duke University Rare Book, Manuscript, and Special Collections Library. Available on the Walt Whitman Archive.

8 My reading of Whitman's poem through the logic of the traveling redwood exhibitions complements the work of those critics, including M. Jimmie Killingsworth, Steven Blakemore, and Jon Noble, who read the felling of the redwood as a trope for the displacement and extinction of Native Americans. The fact that both redwoods and Indians were exhibited at such events as Chicago's World's Fair reinforces the popular nineteenth-century identification of them as natural "curiosities" to be sacrificed to the march of American progress. Some of the earliest illustrations of redwoods included representations of Native Americans, reinforcing that association. Nevertheless, I would suggest, the linked discourses of natural wonder and technological progress characteristic of the traveling redwood exhibits also provide a context for Whitman's poem, one deserving of its own elaboration. See Steven Blakemore and Jon Noble, "Whitman and 'the Indian Problem': The Texts and Contexts of 'Song of the Redwood-Tree," Walt Whitman Quarterly Review 22(Fall 2004 / Winter 2005), 108-125. See also M. Jimmie Killingsworth, "The Voluptuous Earth and the Fall of the Redwood Tree: Whitman's Personifications of Nature," in Ed Folsom, ed., Whitman East and West (Iowa City: University of Iowa Press, 2002), 20.

9 See Cecilia Tichi, New World, New Earth: Environmental Reform in American Literature from the Puritans through Whitman (New Haven: Yale University Press, 1979), 
249. Clarence Major is not the only reader for whom the poem serves as a sort of breaking point with Whitman. Well-known conservationist critics such as M. Jimmie Killingsworth draw the line at the exploitation of nature in the poem. See M. Jimmie Killingsworth, Walt Whitman and the Earth: A Study in Eco-Poetics (Iowa City: University of Iowa Press, 2004), 48-73.

10 Although it is tempting to think of nineteenth-century loggers in pastoral terms, loggers are more properly thought of as workers in one of the period's most important industries, providing the raw material needed to build towns for the nation's expansion.

11 One of these photographs (as well as a number of historical illustrations of redwoods) can be viewed at the on-line California Redwood Archive, developed by Boyd Richard (boydrichard.com/redwood_archive/about.html).

12 For a discussion of globalization in relation to "Song of the Redwood-Tree," see Killingsworth, Walt Whitman and the Earth.

13 Hutchings first published his description of the redwoods in March 1859, in his Hutchings' Illustrated California Magazine, 3 (no. 33). He then included material from the magazine in his 1862 Scenes of Wonder and Curiosity, a collection of articles from the magazine (published in San Francisco by J. M. Hutchings and Co). Afterward, editions of his collected articles were published in New York and San Francisco in 1870 and 1872 as Scenes of Wonder and Curiosity in California. Later editions included a subtitle positioning the book as a "tourist's guide to the Yo-Semite Valley." References are to the 1862 edition listed above, available through Yosemite Open Library (yosemite.ca.us/library).

14 Such a register is mentioned in an 1853 advertisement in The San Francisco Sun Register, October 5, 1853, for the Hanford exhibit on Bush Street.

15 Clarence Major, "September Mendocino." Configurations: New and Selected Poems, 1958-1998 (Copper Canyon Press, 1998), 256-257.

16 See website for the Joshua Grindle Inn (joshgrin.com).

17 Linda Hutcheon, “'Irony, Nostalgia, and the Postmodern': Methods for the Study of Literature as Cultural Memory," Studies in Comparative Literature 30 (2000), 205.

18 Advertisements for the Brewery Gulch Inn, including a description of the salvaging of first-growth redwood logs, can be found at the Inn's website (brewerygulchinn.com). 